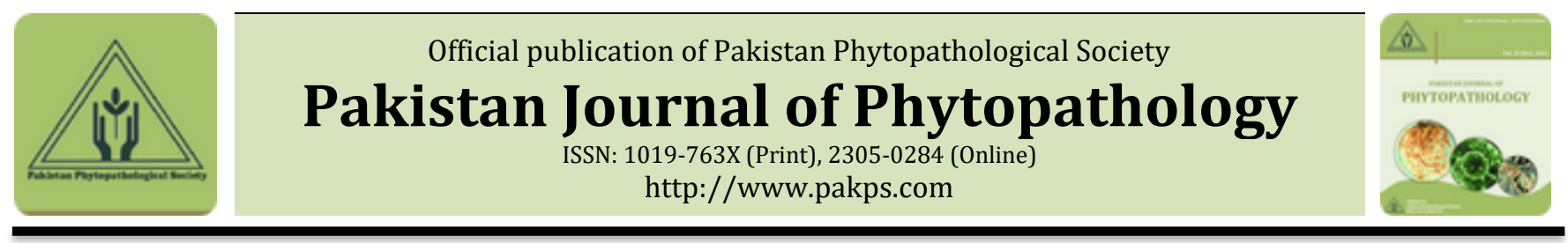

\title{
CHEMICAL COMPOSITION, ANTIBACTERIAL ACTIVITY OF ESSENTIAL OILS AND LEAF EXTRACTS OF MENTHA PULEGIUM (L) AND GLYCYRRHIZA FOETIDA (DESF) AGAINST THE PHYTOPATHOGENIC BACTERIA
}

\author{
aLougraimzi Hanane*, bAghraz Abdellah, cBouaichi Abdelaaziz, dEl J. Meryem, eAchbani E. Hassan \\ ${ }^{a}$ Laboratory of Health, Nutrition and Environment, Faculty of Sciences, Ibn Tofail University, Kenitra, Morocco. \\ ${ }^{b}$ Laboratory of Biotechnology, Protection and Valorisation of Plant Ressources, Faculty of Sciences, Cadi Ayyad \\ University, Semlalia, Morocco. \\ c Laboratory of Botany, Biotechnology and Plant Protection, Faculty of Sciences, Ibn Tofail University, Kenitra, Morocco. \\ ${ }^{d}$ Laboratory of Pharmacology, Faculty of Medicine and Pharmacy, Mohammed V University, Rabat. \\ ${ }^{e}$ Laboratory of Phytobacteriology and Biocontrol, National Institute of Agronomic Research, Meknes, Morocco.
}

\section{A B S T R A C T}

This research was conducted to evaluate the components of the Mentha pulegium (L) and Glycyrrhiza foetida (Desf) that were extracted by hydro distillation and analyzed using GC-MS methods. They are spontaneous plants widespread in Gharb of Morocco. The aim of the study is to investigate the antibacterial activity of the essential oils and leaf methanolic extracts of these two medicinal plants against five phytopathogenic bacteria. The evaluation of the antimicrobial activity of the two species by estimating the diameter of the inhibition zone has shown that the essential oil of M. pulegium exhibited a higher antimicrobial activity than G. foetida which varied according to the sensitivity of the phytopathogenic strains. The results obtained revealed different degrees of sensitivity toward methnolic extract. However, the methanolic extract and the essential oil of M. pulegium are more active based on the Minimal Inhibitory Concentration (MIC) and Minimal Bactericidal Concentration (MBC). The antimicrobial activities of leaf extracts from the two plants highlighted in this study could justify their therapeutic use. These results should be strongly recommended as an alternative to a chemical compound that still represents the problem of toxic residues.

Keywords: Essential oils; Medicinal plant; Antibacterial activity; Leaves extracts; Phytopathogenic bacteria.

\section{INTRODUCTION}

Plant diseases are caused by living organisms (fungi, bacteria, viruses and nematodes) (Messiaen et al., 1991). Phytopathogenic bacteria can live and proliferate. Although they are close to pathogenic germs of humans and animals, they are not able to cause disease on other hosts than plants. However, some of these diseases can have dreadful social and economic consequences; without exaggerating the risks, they must be carefully considered and developed appropriate parries to maintain their impact at an acceptable level (Paulin et

\begin{tabular}{l} 
Submitted: March 14, 2019 \\
Revised: May 17, 2019 \\
Accepted for Publication: May 23, 2019 \\
* Corresponding Author: \\
Email: hananelou04@gmail.com \\
(C) 2017 Pak. J. Phytopathol. All rights reserved. \\
\hline
\end{tabular}

al., 2001). Facing the toxicity problem and taking into account the development and the promotion of organic agriculture by the major importers of Africa in this new world concerned about the health of consumers and to the preservation of the balance of the ecosystems, the ideal would be that the pesticides of the future are natural products biodegradable and able to interfere directly or indirectly with the metabolism of pathogens (Valnet, 1975). The therapeutic virtues of aromatic essences have been known since antiquity, but the interest in the scientific study of the power of aromatic and medicinal plants has increased only in recent years with the aim of seeking alternatives to chemical substances pose risks to human health and the environment (Maisuthisakul et al., 2007).

Morocco, like other Mediterranean countries, is rich in medicinal and aromatic plants that are mostly used in 
traditional medicine to fight against several diseases (Ghourri et al., 2013; Jamila et al., 2014; Youbi et al., 2016). The particular geographical situation of the zone of Gharb offers rich and diversified vegetation. Aromatic plants grow there spontaneously on isolated land and uncultivated plots. Mentha pulegium is a medicinal plant belonging to the family Lamiaceae. Plants of this family include about 160 genera and over 3000 species grown almost all over the world especially in the Mediterranean region (Jafarpour et al., 2013). This species is known as a medicinal plant for its pharmacological and biological properties, it is used in the treatment of colds, sinusitis, cholera, food poisoning, bronchitis and tuberculosis (Shirazi et al., 2004; DíazMaroto et al., 2007). Several studies have examined the antimicrobial activity of this aromatic plant (Mahboubi and Haghi, 2008; Kanakis et al., 2012). Indeed, the pulegone in essential oil has antibacterial activity (Hmiri et al., 2011; Bouyahya et al., 2017).

The genus Glycyrrhiza foetida (Desf) is a plant known as "Guenfdo" in western Morocco (Gharb). According to our survey carried out in 2012, this plant is widely used in traditional medicine by farmers in case of hepatic disorders in cattle, by the constitution of a bed of the fresh plant to which the calf must install 3 days with the change of these leaves every 24 hours.

Therefore, the chemical composition and in vitro bactericidal properties of Mentha pulegium (L) and Glycyrrhiza foetida (Desf) essential oils taken from this area have not yet been valorized; particularly for its antibacterial activity against pathogens agents. The objective of the present work is to study the chemical composition and to investigate, in vitro, the antibacterial activity of essential oils and extracts of Mentha pulegium (L) and Glycyrrhiza foetida (Desf) against phytopathogenic bacteria.

\section{MATERIAL AND METHODS}

Plant material and essential oil extraction: Harvesting of the two plants Mentha pulegium (L) and Glycyrrhiza foetida (Desf) was carried out from plant population of the Gharb zone (located in the northwestern part of Morocco) between April and July 2014. The two plants were identified at the Biodiversity and Natural Substances Laboratory of the Ibn Tofail University of Kenitra-Morocco, on the basis of the document "Practical Flora of Morocco Volume 1, 2 and 3". The plant material was then cut and then dried in the shade at room temperature for four weeks. Leaves were subjected to steam distillation using a Clevenger-type apparatus. Briefly, the plant leaves were completely immersed in water and heated to boiling, after which the essential oil was evaporated together with water vapor and finally collected after decantation. The distillate was isolated and dried in a Rota-vapor to giving an oil. The oil was stored at $4 \mathrm{C}^{\circ}$ until the antimicrobial screening (Song et al., 2009; Ait-Ouazzou et al., 2011).

The yield of essential oils: The yield in OE is the ratio between the weight of the oil extracted and the weight of the plant material used, the yield is expressed as a percentage (\%) is calculated by the following formula (Akrout et al., 2004):

$\mathrm{R}=(\mathrm{Ph} / \mathrm{Pv}) \times 100$

R: Oil yield in \%

$\mathrm{Ph}$ : The weight of oil in $\mathrm{g}$

Pv: The weight of plant material in $\mathrm{g}$.

Gas chromatography-mass spectrometry analysis: The GC-MS unit consisted on a Shimadzu GC-2010 gas chromatograph, equipped with BP-5 capillary column (30 m x 0.25 mm i.d., film thickness $0.25 \mu \mathrm{m}$; SGE, Ltd.), and interfaced with a Shimadzu QP2010 Plus mass spectrometer (software version 2.50 SU1). Oven temperature was programmed, $60-200{ }^{\circ} \mathrm{C}$, at $3{ }^{\circ} \mathrm{C} \cdot \mathrm{min}^{-1}$, and then held isothermal for $5 \mathrm{~min}$; transfer line temperature, $300{ }^{\circ} \mathrm{C}$; ion source temperature, $200{ }^{\circ} \mathrm{C}$; carrier gas, helium, adjusted to a linear velocity of $36.5 \mathrm{~cm} . \mathrm{s}^{-1}$; split ratio, 1:40; ionization energy, $70 \mathrm{eV}$; scan range, 40-400 u; scan time, $1 \mathrm{~s}$. Components identification was carried out by comparison of their retention indices relative to $\mathrm{C}_{9}-\mathrm{C}_{20} n$-alkanes on the BP-5 column confirmed by comparison of recorded mass spectra with those of a computer library (Shimadzu corporation library and NIST05 database/ ChemStation data system) and by comparing with authentic reference compounds whenever possible.

Preparation of methanolic extracts: A sample of $2.5 \mathrm{~g}$ powder leaves was put in $25 \mathrm{ml}$ flask and macerated with absolute methanol under magnetic agitation for 30 min. The extract was then stored at $4{ }^{\circ} \mathrm{C}$ during $24 \mathrm{~h}$, filtered and the solvent was evaporated to dryness under reduced pressure at $50{ }^{\circ} \mathrm{C}$ using a rotary evaporator (Falleh et al., 2008).

Preparation of aqueous extracts: Ten gram of powder was dissolved in $150 \mathrm{ml}$ of distilled water and heated to reflux for $2 \mathrm{~h}$, after cold filtration; the filtrate was then evaporated to dryness under reduced pressure at $65{ }^{\circ} \mathrm{C}$ using a rotary evaporator (Majhenic et al., 2007). 
similar to numerous works already done in Morocco. The research presented by A Bouyahya et al., (2017) showed that pulegone, 1,8-cineole and menthone are the major constituents of $M$. pulegium essential oil with 40.98\%, $23.67 \%$ and $21.16 \%$ concentrations respectively. While, the study conducted by Hmiri et al., (2011) revealed the abundance of pulegone (80.28\%), 1,8-cineole (42.30\%) and $\alpha$-pinene $(28.30 \%)$. This composition is relatively comparable to that of Sylvain Sutour in France, which characterized by the presence of the pulegone (87.7\%),

Table 2. GC-MS data for essential oils components identified

\begin{tabular}{|c|c|c|}
\hline Compound & M. pulegium (\%) & G. feotida (\%) \\
\hline$\alpha$-Pinene & 0.97 & - \\
\hline 3-Octanol & 3.18 & - \\
\hline Limonene & 4.40 & - \\
\hline 1-Terpinenol & 1.12 & - \\
\hline p-Menthone & 19.49 & - \\
\hline Menthol & 6.73 & - \\
\hline Isopulegone & 8.49 & - \\
\hline Pulegone & 35.21 & 4,31 \\
\hline Piperitone & 0.15 & - \\
\hline (+)-Carvone & 0.15 & - \\
\hline Menthyl acetate & 1.68 & - \\
\hline Chrysanthenone & 3.39 & - \\
\hline Caryophyllene & 0.22 & - \\
\hline Dihydrojasmone & 0.13 & - \\
\hline Caryophyllene oxide & 0.28 & 6,51 \\
\hline Myrcene & - & 4,4 \\
\hline trans- $\beta$-damascenone & - & 0,19 \\
\hline$\alpha$-Himachalene & - & 1,72 \\
\hline delta.-Guaiene & - & 0,28 \\
\hline$\beta$-caryophyllene & - & 24,65 \\
\hline$\alpha$-Santalene & - & 0,26 \\
\hline allo-aromadendrene & - & 0,78 \\
\hline Geranyl acetone & - & 0,38 \\
\hline$\alpha$-caryophyllene & - & 2,85 \\
\hline$\beta$-Ionone & - & 0,43 \\
\hline Ledene & - & 0,24 \\
\hline delta.-Cadinene & - & 0,58 \\
\hline Palustrol & - & 1,14 \\
\hline Ledol & - & 0,29 \\
\hline Widdrol & - & 0,56 \\
\hline$\alpha$-Farnesene & - & 1,76 \\
\hline Cembrene & - & 2,05 \\
\hline$\gamma$-cadinene & - & 0,16 \\
\hline$\beta$-Bisabolene & - & 0,93 \\
\hline$\beta$-sesquiphellandrene & - & 0,45 \\
\hline$\beta$-Farnesene & - & 0,56 \\
\hline$\alpha$-Isomethyl ionone & - & 33,27 \\
\hline Phytol & - & 0,4 \\
\hline
\end{tabular}

pipériténone, (2.9\%), menthone, (1.7\%), limonene, (1.5\%) and octan-3-ol, (1.1\%) (Sutour, 2010). The M. pulegium essential oil studied in Iran by Zanjani et al., (2015) showed very low levels of pulegone, cineole, and piperitonone. Their concentrations were $19.89 \%, 19.38 \%$ and $15.14 \%$ respectively. However, another chemotype in Iran exhibited a different composition compared with ours. The frequently found compound was piperitone (38.0\%), piperitenone (33.0\%), terpineol (4.7\%), and pulegone (2.3\%) (Mahboubi and Haghi, 2008).

$(-)$ : not determined 
In this study, we have also analyzed the chemical composition of $G$. foetida essential oil in order to obtain important data on the structure of organic compounds. Thirty-nine compounds were separated and twenty-five of them were identified. Chemical identification of the components has shown that they had been characterized by its high rate of caryophyllene. Indeed, this analyses of essential oil exposed that the major products were $\alpha$ Isomethyl ionone (33.27), $\beta$-Caryophyllene (24.65\%), caryophyllene oxide (6.51\%), Pulregone (4.31\%), myrcene (4.4\%). Our results were different from those previously reported. For example, essential oil of the of Glycyrrhiza glabra aerial parts from western Algeria was characterized by its high rate of Isoniazid and the chemical analysis showed that the major products were methacrylonitrile (9.69\%), benzoic acid (5.37\%), diethyltoluamide (6.56\%), pyrazine, 1,4-carbon dioxide $(2.20 \%)$ benzene $(4.58 \%)$, linalool (2.25\%) and bicyclo [4.1.0] hept-2-ene, 3,7,7trimethyl- (2.80\%) (Chouitah et al., 2011). In Egypt, this same vegetable species (G. foetida) presented another chemotype. It contained geranylhexanolate (34\%), isofenchon (16\%), alpha-terpinene (12.5\%), stragol (9.5\%), beta-caryophyllene (7.7\%), caryophyllene oxide (5.1\%), and octanol (5.1\%) (Ali, 2013). Recently another work conducted in Iran on Glycyrrhiza triphylla Fisch showed a predominance of b-caryophyllene (25.4\%), limonene (16.7\%), b-myrcene (16.0\%) and a-humulene (4.4\%) (Shakeri et al., 2017).

Evaluation of antibacterial activity: The evaluation of the antimicrobial activity of the two species by estimating the diameter of the inhibition zone has shown that the essential oil of M. pulegium exhibited a greater antimicrobial activity than that of $G$. foetida which varies according to the bacterial strains.
The antagonism experiment showed the presence of antibacterial activity of $M$. pulegium aqueous extract against bacterial pathogens A. vitis S4, A. tumefaciens C58 and PCC 2657-1 which were more sensitive. Their corresponding inhibition diameters exceeded $20 \mathrm{~mm}$. Similarly, $A$. tumefaciens C58 and CMM 1616-3 are the most sensitive to the aqueous extract of $G$. foetida with inhibition diameters of 23.6 and $22.6 \mathrm{~mm}$ respectively, unlike the $A$. vitis S4 and PSS 2066-1 which were resistant to treatment. A. vitis S4, A. tumefaciens C58, CMM 1616-3, and PCC 2657-1 presented inhibition zones greater than $20 \mathrm{~mm}$. Therefore they were considered as sensitive to the essential oil of M. pulegium. However, PSS 2066-1 strain showed an inhibition zone of less than $20 \mathrm{~mm}$. The maximum level of inhibition was observed with methanolic extracts of M. pulegium leaves (Figure 1). However, a weak inhibitory activity was recorded against PSS 2066-1 strain. Contrasting, other work revealed the Lawsonia inermis leaves extract had high antibacterial activity against Pseudomonas savastanoi pv. savastanoi and Agrobacterium tumefaciens (Trigui et al., 2013). Thus, other works showed, the ability of the different essential oils of the oregano and thyme spice to retard and inhibit the growth of the different phytopathogenic bacteria; Agrobacterium tumefaciens, Clavibacter michiganensis subsp. michiganensis, Erwinia amylovora, E. herbicola, Pseudomonas syringae, Pseudomonas viridiflava and Xanthomonas axonopodis $p v$. Vesicatoria, (Scortichini and Rossi 1992, Yegen et al., 1998, Daferera et al., 2003). In general, several studies have shown the potential antimicrobial activity of M. pulegium essential oil (Mahboubi, and Haghi, 2008, Teixeira et al., 2012). The study conducted by Zanjani et al (2015) showed a sensitivity of other kinds of strains Bacillus subtilis, Proteus mirabilis and Zygosaccharomyces rouxii with minimum inhibitory concentration values of $0.5 \%, 1.25 \%$, and $1.5 \%$ respectively.

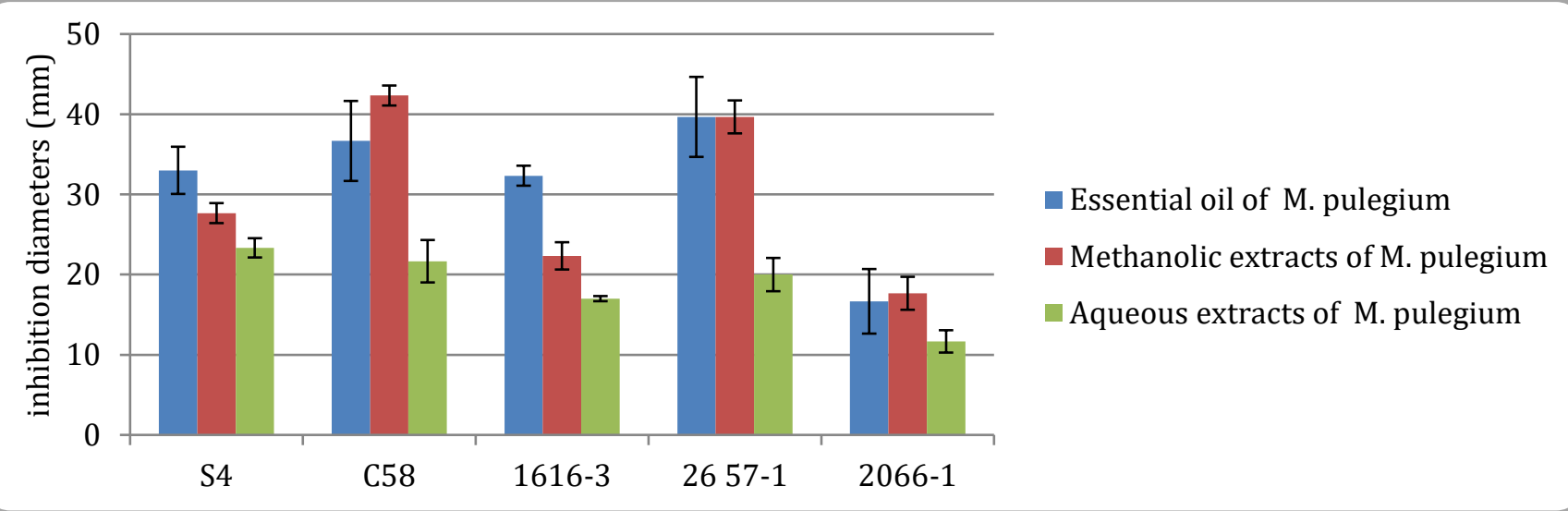

Figure 1. Growth inhibition of phytopathogenic strains (A.vitis s4), (A. tumefaciens C58), (CMM 1616-3), (PCC 2657-1), (PSS 2066-1) using different leaves extracts of M. pulegium. 
The inhibitory effect of $G$. foetida extracts on the growth of phytopathogenic bacteria has shown that the methanolic extract is more effective than the essential oil (Figure 2). However, there was no inhibititory activity recorded by $G$. feotida oil against $A$. vitis S4, PSS 2066-1, PCC 2657-1, compared with A. tumefaciens C58 and CMM 1616-3 which were more sensitive to essential oil, methanolic and aqueous extracts (their inhibition zones exceed $20 \mathrm{~mm}$ ). The results obtained revealed a varied sensitivity of strains to the different extracts. Generally, the methanolic extract and the essential oil of $M$. pulegium are active with Minimal Inhibitory Concentration (MIC) of $10 \mathrm{mg} / \mathrm{ml}$ and $0.25 \%(\mathrm{v} / \mathrm{v}$ ) respectively for methanolic extract and oil, and Minimal Bactericidal Concentration (MBC) values of $10 \mathrm{mg} / \mathrm{ml}$ and $0.5 \%$ respectively for the methanolic extract and oil toward $A$. vitis S4, A. tumefaciens C58), (CMM 1616-3). In addition, the same essential oil showed a bactericidal effect on (PSS 2066-1), (PCC 2657-1) at a concentration of $1 \%$.

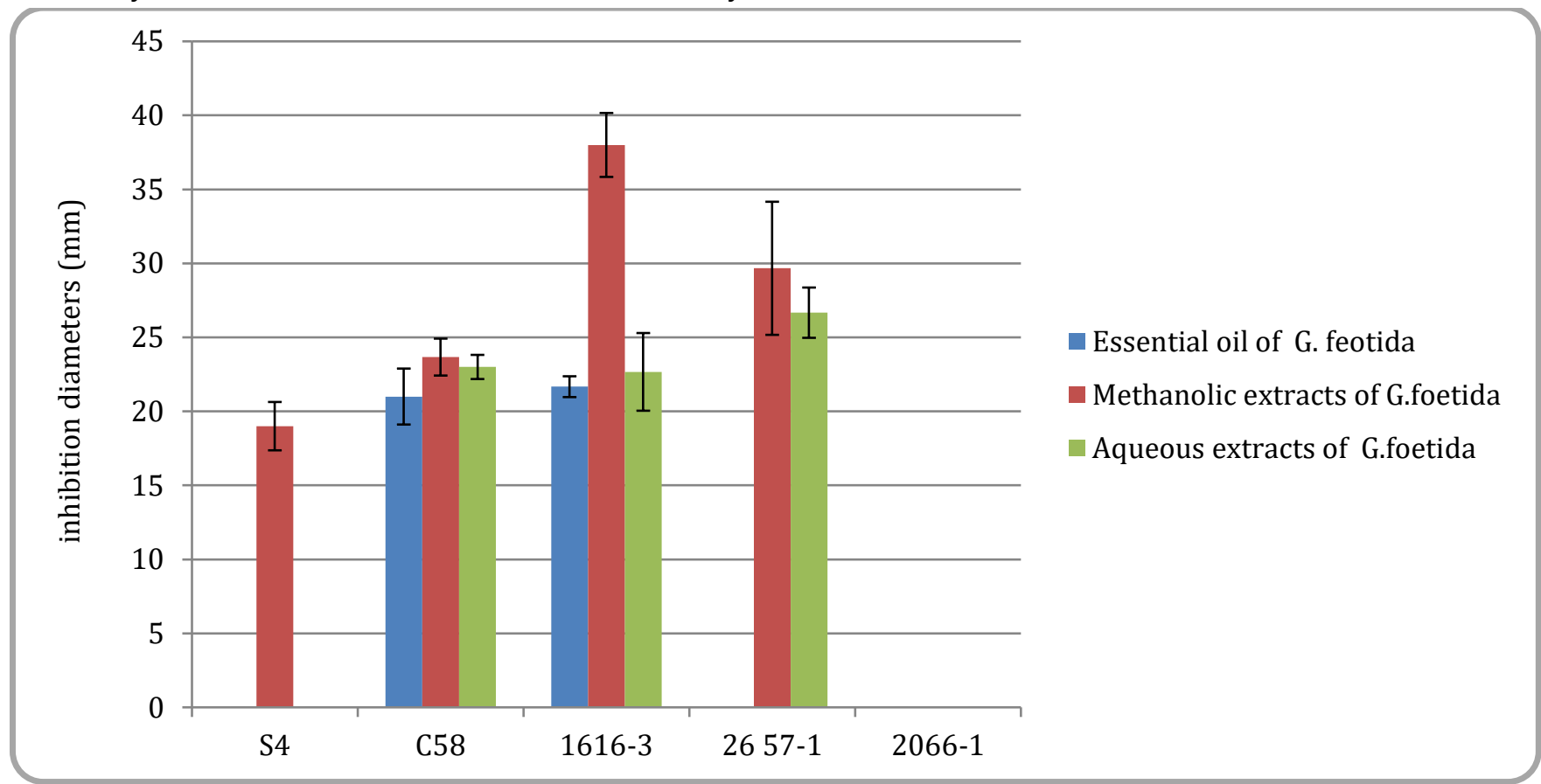

Figure 2. Growth inhibition of phytopathogenic strains (A.vitis s4), (A. tumefaciens C58), (CMM 1616-3), (PCC 2657-1), (PSS 2066-1) using different leaves extracts of $G$. foetida.

The results showed that the aqueous extract of $M$. Salmonella typhi (MIC $14.5 \mathrm{mg} / \mathrm{ml}$ ) and Escherichia coli pulegium has a weak inhibitory activity compared with methanolic extract at different concentrations tested on all bacterial strains. The MIC was $13.33 \mathrm{mg} / \mathrm{ml}$. Nevertheless, the low sensitivity of all strains was observed with the aqueous extract of $G$. foetida with MIC value equal a mean of to $16.67 \mathrm{mg} / \mathrm{ml}$.

Our results showed that the inhibitory and bactericidal activity of $G$. foetida essential oil depended on the bacterial species and strains. Indeed the MIC of $0.5 \%$ (v/v) was obtained against A. vitis S4), A. tumefaciens (C58), but it remained ineffective on the other strains. For the case of the extracts, the MIC is $10 \mathrm{mg} / \mathrm{ml}$ for the methanolic extract and $13,33 \mathrm{mg} / \mathrm{ml}$ for the aqueous extract. Also, Chouitah et al. (2011) reported potent activity of Glycyrrhiza glabra oil against bacteria pathogens like Staphylococcus aureus (MIC $14.5 \mathrm{mg} / \mathrm{ml}$ ),

(MIC: $4,2 \mathrm{mg} / \mathrm{ml}$ ).

The antibacterial effect of our plant (G. foetida) may be due to the main constituents namely b-caryophyllene, limonene, b-myrcene and a-humulene already reported in other plant species (Jirovetz et al., 2006; Qi et al., 2014).

The antimicrobial activities of leaf extracts from both plants highlighted in this study could justify the therapeutic use in traditional medicine for the treatment of a large number of microbial infections.

\section{ACKNOWLEDGEMENTS}

This work was supported by the funds of National Institute of Agronomic Research Meknes, Morocco.

\section{REFERENCES}

Ait-Ouazzou, A., S. Lorán, M. Bakkali, A. Laglaoui, C. Rota, A. Herrera, R. Pagán and P. Conchello. 2011. 
Chemical composition and antimicrobial activity of essential oils of Thymus algeriensis, Eucalyptus globulus and Rosmarinus officinalis from Morocco. Journal of the Science of Food and Agriculture, 91: 2643-2651.

Ali, E. M. 2013. Phytochemical composition, antifungal, antiaflatoxigenic, antioxidant, and anticancer activities of Glycyrrhiza glabra L. and Matricaria chamomilla L. essential oils. Journal of medicinal plants research 729: 2197-2207.

Bouyahya, A., A. Et-Touys, Y. Bakri, A. Talbaui, H. Fellah, J. Abrini and N. Dakka. 2017. Chemical composition of Mentha pulegium and Rosmarinus officinalis essential oils and their antileishmanial, antibacterial and antioxidant activities. Microbial Pathogenesis, 111: 41-49.

Chouitah, O., B. Meddah, A. Aoues and P. Sonnet. 2011. Chemical composition and antimicrobial activities of the essential oil from Glycyrrhiza glabra leaves. Journal of Essential Oil Bearing Plants, 14: 284-288.

Daferera, D. J., B. N. Ziogas and M. G. Polissiou. 2003. The effectiveness of plant essential oils on the growth of Botrytis cinerea, Fusarium sp. and Clavibacter michiganensis subsp. michiganensis. Crop Protection, 22: 39-44.

Díaz-Maroto, M. C., N. Castillo, L. Castro-Vázquez, M. Ángel González-Viñas and M. S. Pérez-Coello. 2007. Volatile composition and olfactory profile of pennyroyal (Mentha pulegium L.) plants. Flavour and Fragrance Journal, 22: 114-118.

Falleh, H., R. Ksouri, K. Chaieb, N. Karray-Bouraoui, N. Trabelsi, M. Boulaaba and C. Abdelly. 2008. Phenolic composition of Cynara cardunculus L. organs, and their biological activities. Comptes Rendus Biologies, 331: 372-379.

Ghourri, M., L. Zidane and A. Douira. 2014. Catalogue des plantes médicinales utilisées dans le traitement de la lithiase rénale dans la province de Tan-Tan (Maroc saharien). International Journal of Biological and Chemical Sciences, 7:1688.

Hmiri, S., M. Rahouti, Z. Habib, B. Satrani, M. Ghanmi and M. El Ajjouri. 2011. Évaluation du potentiel antifongique des huiles essentielles de Mentha pulegium et $d^{\prime}$ Eucalyptus Camaldulensis dans la lutte biologique contreles champignons responsables de la détérioration des pommes en conservation. Bulletin de la société royale des sciences de liège.
Ismaili, H., L. Milella, S. Fkih-Tetouani, A. Ilidrissi, A. Camporese, S. Sosa, G. Altinier, R. Della Loggia and R. Aquino. 2004. In vivo topical anti-inflammatory and in vitro antioxidant activities of two extracts of Thymus satureioides leaves. Journal of Ethnopharmacology, 91: 31-36.

Jafarpour, M., A. R. Golparvar and A. Lotfi. 2013. Antibacterial activity of essential oils from Thymus vulgaris, Trachyspermum ammi and Mentha aquatica against Erwinia carotovora in vitro. Journal of Herbal Drugs (An International Journal on Medicinal Herbs), 4: 115-118.

Jamila, F. and E. Mostafa. 2014. Ethnobotanical survey of medicinal plants used by people in Oriental Morocco to manage various ailments. Journal of Ethnopharmacology, 154: 76-87.

Jirovetz, L., S. Bail, G. Buchbauer, Z. Denkova, A. Slavchev, A. Stoyanova, E. Schmidt and M. Geissler. 2006. Antimicrobial testings, gas chromatographic analysis and olfactory evaluation of an essential oil of hop cones (Humulus lupulus L.) from Bavaria and some of its main compounds. Scientia Pharmaceutica, 74: 189.

Kanakis, C. D., E. A. Petrakis, A. C. Kimbaris, C. Pappas, P. A. Tarantilis and M. G. Polissiou. 2012. Classification of Greek Mentha pulegium L. (Pennyroyal) samples, according to geographical location by Fourier transform infrared spectroscopy. Phytochemical analysis, 23: 34-43.

Mahboubi, M. and G. Haghi. 2008. Antimicrobial activity and chemical composition of Mentha pulegium $\mathrm{L}$. essential oil. Journal of Ethnopharmacology, 119: 325-327.

Maisuthisakul, P., M. Suttajit and R. Pongsawatmanit. 2007. Assessment of phenolic content and free radical-scavenging capacity of some Thai indigenous plants. Food Chemistry, 100: 14091418.

Majhenič, L., M. Škerget and Ž. Knez. 2007. Antioxidant and antimicrobial activity of guarana seed extracts. Food Chemistry, 104: 1258-1268.

Messiaen, C.-M., D. Blancard and F. Rouxel. 1991. Les maladies des plantes maraîchères, $3 e$ éd. Editions Quae.

Paulin, J.-P., M. Ridé and J.-P. Prunier. 2001. Découverte des bactéries phytopathogènes il $\mathrm{y}$ a cent ans : controverses et polémiques transatlantiques. Comptes Rendus de l'Académie des Sciences - 
Series III - Sciences de la Vie, 324: 905-914.

Popoff, M. Y., K. Kersters, M. Kiredjian, I. Miras and C. Coynault. 1984. Position taxonomique de souches de Agrobacterium d'origine hospitalière. Annales de l'Institut Pasteur / Microbiologie, 135: 427-442.

Qi, X.-L., T.-T. Li, Z.-F. Wei, N. Guo, M. Luo, W. Wang, Y.-G. $\mathrm{Zu}, \mathrm{Y}$.-J. $\mathrm{Fu}$ and $\mathrm{X}$. Peng. 2014. Solvent-free microwave extraction of essential oil from pigeon pea leaves [Cajanus cajan (L.) Millsp.] and evaluation of its antimicrobial activity. Industrial Crops and Products, 58: 322-328.

Remmal, A., T. Bouchikhi, K. Rhayour, M. Ettayebi and A. Tantaoui-Elaraki. 1993. Improved method for the determination of antimicrobial activity of essential oils in agar medium. Journal of Essential Oil Research, 5: 179-184.

Scortichini, M. and M. Rossi. 1992. In vitro behaviour of Erwinia amylovora towards some natural products showing bactericidal activity. VI International Workshop on Fire Blight 338. pp. 191-198.

Shakeri, A., J. Akhtari, V. Soheili, S. F. Taghizadeh, A. Sahebkar, R. Shaddel and J. Asili. 2017. Identification and biological activity of the volatile compounds of Glycyrrhiza triphylla Fisch. \& C.A. Mey. Microbial Pathogenesis, 109: 39-44.

Shirazi, F. H., N. Ahmadi and M. Kamalinejad. 2004. Evaluation of northern Iran Mentha pulegium L. cytotoxicity. DARU Journal of Pharmaceutical Sciences, 12: 106-110.

Song, A., Y. Wang and Y. Liu. 2009. Study on the chemical constituents of the essential oil of the leaves of Eucalyptus globulus Labill from China. Asian Journal of Traditional Medicines, 4: 34-140.

Sutour, S. 2010. Etude de la composition chimique d'huiles essentielles et d'extraits de menthe de
Corse et de Kumquats. Université de Corse.

Teixeira, B., A. Marques, C. Ramos, I. Batista, C. Serrano, O. Matos, N. R. Neng, J. M. F. Nogueira, J. A. Saraiva and M. L. Nunes. 2012. European pennyroyal (Mentha pulegium) from Portugal: Chemical composition of essential oil and antioxidant and antimicrobial properties of extracts and essential oil. Industrial Crops and Products, 36: 81-87.

Trigui, M., A. Ben Hsouna, I. Hammami, G. Culioli, M. Ksantini, S. Tounsi and S. Jaoua. 2013. Efficacy of Lawsonia inermis leaves extract and its phenolic compounds against olive knot and crown gall diseases. Crop Protection, 45: 83-88.

Valnet, J. 1975. Aromatherapie: Traitement des maladies par les essences des plantes (7. revue, corr. et augm. ed.). Paris, France: Maloine. Includes Bibliography: 429-434.

Yegen, O., A. Unlu and B. Berger. 1998. Use and side effects on the soil microbial activity of the essential oil from Thymbra spicata to control pepper blight Phytophthora capsici. Zeitschrift fur Pflanzenkrankheiten und Pflanzenschutz, 105: 602610.

Youbi, A., I. Ouahidi, L. Mansouri, A. Daoudi and D. Bousta. 2016. Ethnopharmacological survey of plants used for immunological diseases in four regions of Morocco. European Journal of Medicinal Plants, 13: 1-24.

Zanjani, K., N. Mohammadi, M. Zojaji and H. Bakhoda. 2015. Chemical Composition of the Essential Oil of Mentha pulegium L. and its Antimicrobial Activity on Proteus mirabilis, Bacillus subtilis and Zygosaccharomyces rouxii. Journal of Food Biosciences and Technology, 5: 31-40. 